\title{
Intramural haematoma of the oesophagus
}

\author{
Ayu Mitsutake, ${ }^{1}$ Yukinori Harada, ${ }^{02}$ Akihiko Tomita, ${ }^{1}$ Kunihiko Ueshima ${ }^{1}$
}

${ }^{1}$ Internal Medicine, Matsumoto Kyoritsu Hospital, Matsumoto, Nagano, Japan

${ }^{2}$ Diagnostic and Generalist Medicine, Dokkyo Medical University, Shimotsuga-gun, Tochigi, Japan

\section{Correspondence to} Dr Yukinori Harada, yuki.gym23@gmail.com

Accepted 26 June 2019

\section{DESCRIPTION}

An 89-year-old man presented to the emergency department with sudden-onset chest pain, vomiting and nausea after swallowing rice. His medical history included acute coronary syndrome that was treated with a percutaneous coronary intervention using drug-eluting stents. Moreover, he was taking $100 \mathrm{mg}$ of aspirin and $100 \mathrm{mg}$ of ticlopidine orally. Physical examination revealed stable vital signs, except hypertension (blood pressure: 170/88 mm $\mathrm{Hg}$ ) and tenderness at the epigastrium and the right upper quadrant of the abdomen. Laboratory tests revealed that the white blood cell count was elevated to $12100 / \mathrm{mm}^{3}$; however, no evidence of anaemia, thrombocytopaenia, coagulative disorder or myocardial injury was observed. A chest CT scan without contrast revealed diffuse thickening of the oesophageal wall (figure 1A).

The patient was admitted because of suspected oesophageal bleeding. We initiated the treatment by stopping his medication and food and administering proton-pump inhibitor (PPI) intravenously. On the next day, a chest CT scan with contrast revealed a concentric intramural haematoma without evidence of extravasation (figure 1B). Upper endoscopy detected protrusion of the dark-purple-coloured oesophageal wall that was oozing blood (figure 2A). Based on these findings, we established diagnosis of acute intramural haematoma of the oesophagus (IHE). We continued intravenous PPI and fasting until follow-up endoscopy on day 6 , at which time, we observed an alteration in the haematoma to longitudinal ulcerated mucosa without bleeding (figure 2B). Thereafter, the patient was allowed to eat and take PPI orally. His epigastric pain resolved entirely on day 10 , and he was discharged on day 13. The patient began anticoagulation for a new stroke with atrial fibrillation on day 23. On day 46, the endoscopy revealed a recovered oesophageal wall (figure 2C), and the patient restarted taking aspirin and ticlopidine. On day 74, the patient

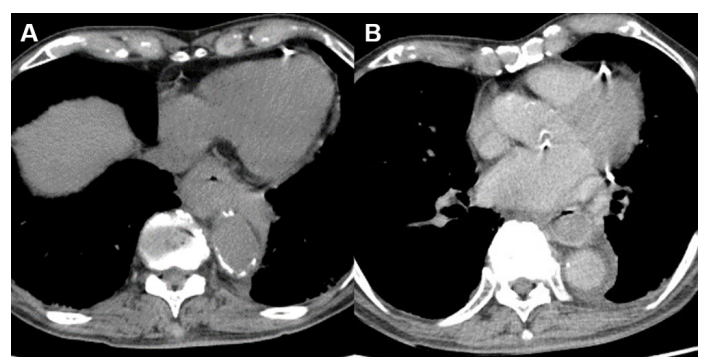

Figure 1 On the day of admission, chest CT without contrast shows the diffuse thickness of the oesophageal wall (A). On day 2 , chest $C T$ with contrast reveals a concentric intramural haematoma (B).

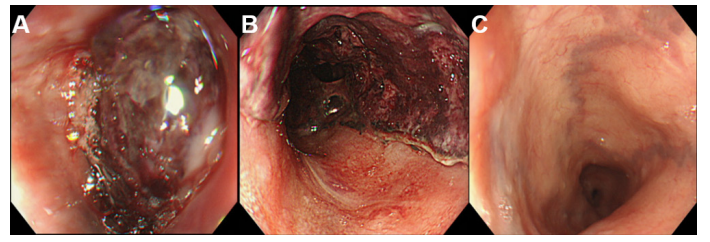

Figure 2 Serial endoscopy of the oesophagus on day 2 (A), day 6 (B) and 1 month after discharge (C) shows the typical healing stages of intramural haematoma of the oesophagus.

stopped taking aspirin and continued with ticlopidine and apixaban.

Reportedly, IHE is a result of haemorrhaging within the oesophageal wall. ${ }^{1}$ A precise diagnosis of IHE is crucial because $>80 \%$ of the patients with IHE present with sudden or acute chest pain that might be mistaken as a symptom of coronary artery disease or aortic disease. ${ }^{2}$ Patient history appears to be important for making an early diagnosis of IHE. Both older age and antiplatelet drugs are recognised as risk factors of IHE, ${ }^{1}$ and swallowing of food or drink is considered a common precipitating factor of IHE. ${ }^{2}$

Although upper endoscopy has been reported to be commonly performed in patients suspected with IHE ${ }^{2}$ CT seems to be a more favourable technique for diagnosing IHE as compared with endoscopy in terms of safety and its capability for excluding other differential diagnoses. ${ }^{12} \mathrm{CT}$ typically reveals symmetric or asymmetric oesophageal wall thickening with a concentric or eccentric intramural oesophageal mass. ${ }^{1}$

IHE has a benign course, and the symptoms can disappear in the majority of the patients within 2 weeks. ${ }^{2}$ Generally, most patients with IHE should be treated conservatively with a short period of intravenous fluid administration. Moreover, ulcerhealing drugs, such as PPI or H2-antagonists, might be useful because ulceration can be considered a stage in the healing of the oesophagus, as observed in our patient. ${ }^{2}$ Invasive therapy should be avoided in patients with IHE because adverse events commonly occur with this procedure. ${ }^{2}$ However, in patients with severe complications, such as severe bleeding, perforation or intramural abscess or in case of failure of conservative treatment, invasive therapies, such as operation, endoscopic treatment or therapeutic, angiography should be considered as therapeutic options. ${ }^{23}$

Contributors $\mathrm{AM}$ and $\mathrm{YH}$ : wrote the initial draft. AT and $\mathrm{KU}$ : made critical revisions. All authors approved the manuscript as submitted to the journal. 


\section{Learning points}

Intramural haematoma of the oesophagus should be considered as a differential diagnosis in elderly patients who are on antiplatelet drugs and have acute chest pain after swallowing food.

- Intramural haematoma of the oesophagus can be treated conservatively with a short period of intravenous fluid administration.

Funding The authors have not declared a specific grant for this research from any funding agency in the public, commercial or not-for-profit sectors.

Competing interests None declared.

Patient consent for publication Obtained.

Provenance and peer review Not commissioned; externally peer reviewed.

\section{REFERENCES}

1 Restrepo CS, Lemos DF, Ocazionez D, et al. Intramural hematoma of the esophagus: a pictorial essay. Emerg Radiol 2008;15:13-22.

2 Cullen SN, McIntyre AS. Dissecting intramural haematoma of the oesophagus. Eur J Gastroenterol Hepatol 2000;12:1151-62.

3 Shim J, Jang JY, Hwangbo Y, et al. Recurrent massive bleeding due to dissecting intramural hematoma of the esophagus: treatment with therapeutic angiography. World J Gastroenterol 2009;15:5232-5.

Copyright 2019 BMJ Publishing Group. All rights reserved. For permission to reuse any of this content visit

https://www.bmj.com/company/products-services/rights-and-licensing/permissions/

BMJ Case Report Fellows may re-use this article for personal use and teaching without any further permission.

Become a Fellow of BMJ Case Reports today and you can:

- Submit as many cases as you like

- Enjoy fast sympathetic peer review and rapid publication of accepted articles

- Access all the published articles

Re-use any of the published material for personal use and teaching without further permission

Customer Service

If you have any further queries about your subscription, please contact our customer services team on +44 (0) 2071111105 or via email at support@bmj.com.

Visit casereports.bmj.com for more articles like this and to become a Fellow 